\title{
Konservasi Koleksi Lukisan Museum Le Mayeur
}

\author{
I Made Suparma Netra*, Nyoman Wardi \\ Prodi Arkeologi, Fakultas Ilmu Budaya, Unud \\ [madesuparma8@gmail.com], [wardi_ecoculture@yahoo.co.id] \\ Gianyar, Bali, Indonesia \\ *Corresponding Author
}

\begin{abstract}
As a result of human work, painting is a cultural heritage that has important values. The state of the structure of the paintings which is composed by organic materials makes the painting very vulnerable to the environmental influences and other causes of damage. This research aims to find out about the characteristics of the painting, the types of damage, the factors that cause damage, and its conservation techniques both preventive and and curative to painting collection of Le Mayeur Museum. The results of this research are expected to provide benefits and development of science in the field of archeology about the study of cultural heritage conservation. This study uses qualitative analysis, technology analysis, and comparative analysis. Data collection technique used are direct observation technique, interviews, and library reserach studies. The theories applied are Aesthetic Theory and Conservation Theory. The results obtained namely the characteristic of Le Mayeur's paintings are representative with women's theme and surroundings life, the coloring technique using plaque technique with oil paint, watercolor, traditional paint, and pastels color. Generally, there are several types of damage to the painting collection of Le Mayeur Museum, such as physical or mechanic damage, biotic damage, and chemical damage. Those types of damage are caused by physical factors, , chemistry factors, biotic factors, and human factors. The conservation techniques carried out at the Le Mayeur Museum include preventive conservation and curative conservation. The preventive actions are carried out with control of temperature, air humidity, intensity of ultraviolet light, and control of air containing salt due to sea water vapor. The curative actions taken are semichemist medicine and painting restoration.
\end{abstract}

Keywords: painting, characteristics, types of damage, destructive factors, and conservation

\begin{abstract}
Abstrak
Lukisan sebagai hasil karya manusia merupakan warisan budaya yang memiliki nilai penting. Keadaan struktur lukisan yang tersusun oleh bahanbahan organik membuat lukisan sangat rentan dengan pengaruh lingkungan dan penyebab kerusakan lainnya. Penelitian ini bertujuan untuk mengetahui lebih mendalam mengenai karakteristik lukisan, jenis-jenis kerusakan,
\end{abstract}


faktor-faktor penyebab kerusakan, dan teknik konservasinya baik itu preventif maupun kuratif terhadap koleksi lukisan Museum Le Mayeur. Hasil penelitian ini diharapkan dapat memberikan manfaat dan pengembangan ilmu pengetahuan di bidang arkeologi, yaitu tentang studi konservasi warisan budaya. Penelitian ini menggunakan analisis kualitatif, analisis teknologi, dan analisis komparatif. Teknik pengumpulan data yang digunakan yaitu teknik pengamatan dengan observasi langsung, wawancara, dan studi kepustakaan. Beberapa teori juga digunakan seperti Teori Estetika dan Teori Konservasi. Hasil yang diperoleh, yaitu karakteristik dari lukisan Le Mayeur adalah representatif dengan tema wanita dan kehidupan sekitar, teknik pewarnaan menggunakan teknik plakat dengan cat minyak, cat air, cat tradisional, dan pastel. Secara umum terdapat beberapa jenis kerusakan koleksi lukisan Museum Le Mayeur seperti kerusakan secara fisik atau mekanik, kerusakan secara biotis, dan kerusakan secara kimiawi. Berbagai jenis kerusakan ini disebabkan oleh faktor fisis, faktor kemis, faktor biotis, dan faktor manusia. Teknik konservasi yang dilakukan di Museum Le Mayeur meliputi konservasi preventif dan konservasi kuratif. Tindakan preventif dilakukan dengan kontrol terhadap suhu, kelembaban udara, intensitas sinar ultraviolet, dan kontrol terhadap udara yang mengandung garam akibat uap air laut. Tindakan kuratif yang ditempuh yaitu dengan pengobatan semi kemis dan restorasi lukisan.

Kata kunci: lukisan, karakteristik, jenis kerusakan, faktor perusak, dan konservasi.

\section{Latar Belakang}

Penciptaan seni sebagai sebuah keindahan telah ada sejak Zaman Prasejarah. Seni cadas merupakan suatu hasil karya seni manusia masa lampau yang dilukiskan pada dinding gua atau ceruk, tebing karang, dan pada permukaan batu besar. Hasil karya seni tersebut merupakan himpunan simbol atau lambang yang mengandung nilai kehidupan (Fairyo, 2016:118).

Di Bali khususnya, secara historis istilah seni lukis sudah dikenal sekitar abad ke-11 pada Prasasti Pandak Gede ditemukan ada goresan berbentuk wayang pada hiasan pelita perunggu.

Perkembangan seni lukis yang lebih dinamis lahir dari puncak peradaban Bali di masa kekuasaan Raja Dalem Waturenggong di Gelgel.

Setelah masuknya pengaruh pengaruh seniman Eropa barulah seni lukis di Bali mengalami modernisasi.
Seni lukis Bali yang sebelumnya hanya berkutat pada seni lukis wayang tradisional mulai berkembang dengan mengenal teknik-teknik visualisasi yang lebih modern. Perbaharuan yang dibawa oleh seniman Eropa berupa pengetahuan bentuk, plastisitas, pengolahan ruang, dan teknik melukis secara lebih eflsien. Objek yang dilukiskan tidak lagi hanya tentang pewayangan dalam cerita-cerita Mahabharata dan Ramayana, melainkan perkembangan pada tema-tema kehidupan sosial masyarakat dan fenomena alam di sekitarnya.

Salah seorang yang membawa pengaruh gaya lukisan dari Eropa yaitu Adrien Jean Le Mayeur de Merpres yang berasal dari Belgia. Dia datang ke Bali sekitar tahun 1932 karena tertarik dengan kehidupan masyarakat di Bali khususnya para perempuan serta kisah cintanya terhadap salah seorang perempuan dari Bali bernama Ni Pollok sehingga 
lukisannya kebanyakan bertemakan romantika perempuan Bali dan suasana kehidupan masyarakat Bali pada waktu itu. Lukisan Le Mayeur hingga saat ini disimpan di Museum Le Mayeur yang berada di Sanur.

Museum Le Mayeur merupakan salah satu museum dengan bangunan berarsitektur Bali yang menampung 88 buah lukisan yang dibagi menjadi lima jenis koleksi berdasarkan media yang dipakai, yaitu Bagor (22 lukisan), Hard Board (25 lukisan), Triplek (6 lukisan), Kertas (7 lukisan), dan Kanvas (28 lukisan). Dari 88 koleksi lukisan tersebut, 4 dibuat pada tahun 1921, 4 dibuat tahun 1927, 3 dibuat tahun 1928, 28 dibuat tahun 1929, 3 dibuat tahun 1937, 14 dibuat tahun 1938, 23 dibuat tahun 1942, dan 10 lukisan lagi dibua tahun 1957.

Jika ditinjau berdasarkan faktor umur, koleksi lukisan Museum Le Mayeur adalah koleksi lukisan yang telah mencapai usia sekitar 50 tahun lebih. Dari salah satu penjelasan UndangUndang Republik Indonesia No. 11 Tahun 2010 tentang Cagar Budaya, sesuai Pasal 5 bagian kesatu dapat menjadi salah satu dasar hukum bahwa koleksi lukisan Museum Le Mayeur khusus untuk lukisan yang telah berumur lebih dari 50 tahun dapat dikatagorikan sebagi benda Cagar Budaya. Sejauh ini informasi yang didapatkan bahwa Museum Le Mayeur belum ditetapkan sebagai Cagar Budaya, namun memiliki potensi untuk ditetapkan sebagai Cagar Budaya kedepannya.

Pada tanggal 28 Agustus 1957 telah terjadi dua peristiwa bersejarah yang berkaitan dengan keberadaan Museum Le Mayeur. Pertama, Adrean Jean Le Mayeur de Merpres berdasarkan atas Akte Hadiah (Schenking) nomor 37 telah menghadiahkan hak miliknya yang terhimpun dalam perusahaan Seni Lukis yang terletak di pantai Sanur kepada Ni Nyoman Pollok. Kedua, Ni Nyoman
Pollok selaku pewaris dari perusahaan tersebut selanjutnya menghadiahkan lagi kepada Departemen Pendidikan Pengajaran dan Kebudayaan R.I berdasarkan atas Akte Hadiah nomor 38. Berdasarkan atas peristiwa tersebut, maka sejak tanggal 28 Agustus 1957 perusahaan Seni Lukis yang kini lebih dikenal dengan nama Museum Le Mayeur telah sah menjadi milik negara. Museum Le Mayeur saat ini berada di bawah Dinas Kebudayaan Pemerintah Provinsi Bali, UPT. Museum Bali. Bangunan Museum Le Mayeur termasuk Historic House Museum (Museum Rumah Bersejarah) karena berisi koleksi dan benda-benda peninggalan yang asli serta jejak memori dari orang-orang yang pernah tinggal di sana.

Sesuai kebijakan pengembangan permuseuman di Indonesia yang berpedoman pada rumusan ICOM (International Council of Museum), Museum Le Mayeur harus berpatokan sesuai dengan peraturan permuseuman di Indonesia. Fungsi tersebut salah satunya adalah konservasi dan preservasi (Tjahjopurnomo dkk, 2012:24).

Berpedoman pada fungsi museum yang salah satunya adalah perawatan dan pemeliharaan (konservasi) dengan mengacu pada keadaan koleksi lukisan yang rentan akan kerusakan maka Museum Le Mayeur haruslah melakukan tindakan pemeliharaan dan pencegahan kerusakan koleksi lukisannya dengan cara konservasi maupun restorasi lukisan. Berbicara terkait konservasi lukisan di Museum Le Mayeur tentunya tidak bisa lepas perhatian terhadap bangunan tempat lukisan itu disimpan dan dipamerkan serta kondisi lingkungan di sekitar museum.

Fakta yang banyak ditemui di lapangan yaitu cukup sering terjadi kekeliruan dalam perawatan sebuah lukisan. Hal ini dikarenakan kurangnya pengetahuan dan sumberdaya manusia 
yang menguasai keahlian tentang teknik konservasi lukisan di Indonesia, khususnya di Bali. Akibat sulitnya melakukan perawatan koleksi lukisan, maka dibutuhkan orang atau lembaga yang mampu menjaga dan merawat lukisan sebagai sebuah karya seni yang memiliki signifikasi budaya yaitu fungsi, nilai sejarah, nilai estetis budaya, simbolik atau nilai keilmuan, dan nilai sosial sehingga sangat penting artinya untuk diselamatkan.

Sejauh ini belum pernah ada penelitian yang membahas mengenai konservasi koleksi lukisan di Museum Le Mayeur, baik itu konservasi preventif maupun kuratifnya. Peneliti mencoba lebih dalam untuk mengungkap tentang teknik konservasi lukisan, mengingat sedikit dan kurangnya sumberdaya manusia dan tenaga ahli konservasi museum yang ada di Bali khususnya di Museum Le Mayeur.

Penelitian ini menggunakan pendekatan teori dan komparasi dengan museum yang memiliki kesamaan koleksi dengan Museum Le Mayeur sehingga dapat membantu mengungkap karakteristik koleksi lukisan di Museum Le Mayeur.

\section{Pokok Permasalahan}

a) Bagaimana karakteristik koleksi lukisan Museum Le Mayeur dilihat dari aspek gaya, tema, dan teknik pewarnaan?

b) Jenis-jenis kerusakan apa saja yang terjadi pada koleksi lukisan Museum Le Mayeur dan faktor apa yang menyebabkan?

c) Bagaimana teknik konservasi koleksi lukisan yang dilakukan oleh Museum Le Mayeur?

\section{Tujuan Penelitian}

a) Secara umum penelitian ini dilakukan untuk mengetahui karakteristik objek penelitian tentang konservasi koleksi lukisan sebagai warisan budaya yang memiliki nilai sejarah, seni, tradisi, nilai estetis, dan keilmuan. Bali telah menciptakan dan mengembangkan berbagai kesenian khususnya seni lukis sebagai salah satu pendongkrak pariwisata di Bali, sehingga perlu menjaga kelestarian dan merawat koleksi lukisan sebagai warisan budaya baik oleh museum, gallery lukisan, dan para kolektor lukisan.

b) Mengetahui karakteristik koleksi lukisan Museum Le Mayeur dilihat dari aspek gaya, tema, dan teknik pewarnaan. Mengklasifikasi jenis kerusakan dan mengetahui faktorfaktor yang menyebabkan kerusakan pada koleksi lukisan di Museum Le Mayeur. Melalui penelitian ini diharapkan dapat menjawab tentang langkah-langkah yang dilakukan untuk mengkonservasi lukisan sebagai langkah pencegah kerusakan lukisan lebih lanjut. Diharapkan juga agar memberi manfaat terhadap ilmu pengetahuan bidang Arkeologi, khususnya studi konservasi warisan budaya

\section{Metode Penelitian}

Penelitian ini menggunakan teori konservasi dan estetika. Teori konservasi dalam penelitian ini akan digunakan sebagai pedoman untuk menjelaskan permasalahan terkait dengan teknik konservasi koleksi lukisan di museum Le Mayeur. Lukisan adalah sebagai hasil karya manusia yang tentunya memiliki nilai artistik atau nilai seni yang merupakan ekspresi curahan perasaan si penciptanya atau ungkapan masyarakat pendukungnya. Untuk menilai estetis pada lukisan digunakanlah Teori estetika sehingga secara keseluruhan penulis dapat melihat tema lukisan, motif, warna, dan makna yang terkandung dalam lukisan tersebut. 
Penelitian ini menggunakan beberapa metode analisis data, yaitu analisis kualitatif, analisis teknologi, dan analisis komparatif. Analisis kualitatif ini digunakan untuk memperoleh data dan informasi tentang teknik konservasi lukisan. Data tersebut berupa dokumen pelaksanaan konservasi yang telah dilakukan museum maupun praktikum konservasi yang diikuti penulis. Analisis teknologi digunakan untuk mengetahui teknik pembuatan lukisan berdasarkan substrat, pewarna, dan gaya/aliran yang digunakan oleh si pelukis. Analisis komparatif merupakan suatu metode membandingkan untuk mencari perbedaan maupun persamaan suatu objek. Peneliti membandingkan lukisan Le Mayeur dengan koleksi lukisan di Museum Puri Lukisan Ubud dilihat dari aspek gaya, tema, dan teknik pewarnaannya.

\section{Hasil Dan Pembahasan}

\subsection{Gambaran Umum Museum Le Mayeur}

Museum Le Mayeur merupakan museum khusus yang hanya memamerkan koleksi lukisan dari seorang pelukis bernama Adrien Jean Le Mayeur de Merpres. Pelukis yang berasal dari Belgia ini awalnya datang ke Bali pada tahun 1932 dengan rencana hanya tinggal beberapa hari saja dalam perjalanan karirnya melanglang buana ke berbagai negara untuk melukis. Melihat suasana alam Bali dan perempuan Bali, salah satunya Ni Nyoman Pollok. Le Mayeur menjadi tertarik untuk tinggal di Bali dan menjadikan Ni Nyoman Pollok sebagai model lukisannya. Le Mayeur bersama $\mathrm{Ni}$ Nyoman Pollok berhasil meraih kesuksesan dalam pamerannya di Singapura, lalu hubungan mereka semakin serius dan menuju ke jenjang pernikahan pada tahun 1935. Mereka lantas membangun rumah di pantai Sanur secara bertahap dari hasil pamerannya. Ketenaran Le Mayeur semakin meningkat, pengunjungpun berdatangan ke rumah Le Mayeur, hingga pejabat tinggi negara mengunjunginya seperti Presiden Soekarno, Perdana Menteri India Nehru, dan Bapak Bahder Djohan Menteri Pendidikan Pengajaran dan Kebudayaan R.I yang sekaligus meminta melestarikan karya seni tersebut dan menjadikannya museum. Pada tanggal 28 Agustus 1957 secara sah Le Mayeur dan Ni Nyoman Pollok mempersembahkan rumah beserta isinya pada negara untuk dijadikan museum. Museum Le Mayeur saat ini berada di bawah Dinas Kebudayaan Provinsi Bali, UPT. Museum Bali. Museum Le Mayeur menyimpan koleksi lukisan sebanyak 88 buah lukisan dengan substrat kanvas, kertas, bagor, triplek, dan hardboard.

\subsection{Karakterisik, jenis-jenis kerusakan, dan faktor penyebab kerusakan koleksi lukisan Museum Le Mayeur \\ Museum Le Mayeur merupakan} museum yang menyimpan koleksi lukisan dan memiliki karakteristik tertentu dari seorang pelukis bernama Le Mayeur dari Belgia. Berdasarkan hasil penelitian penulis, setelah mengamati koleksi lukisan di Museum Le Mayeur dan melakukan perbandingan dengan koleksi lukisan di Museum Puri Lukisan Ubud mendapatkan hasil sebagai berikut.

Karakteristik koleksi lukisan di Museum Le Mayeur dilihat dari aspek gaya, tema, dan teknik pewarnaannya, yaitu dari gaya lukisan di Museum Le Mayeur tergolong kedalam representatif. Representatif adalah gaya lukisan yang menggambarkan keadaan nyata kehidupan di masyarakat dan gaya alam sekitar. Tema dari lukisan koleksi Museum Le Mayeur kebanyakan tentang wanita dan kehidupan sekitar. Teknik pewarnaan lukisan Museum Le Mayeur 
menggunakan teknik plakat menggunakan sapuan kuas dan memakai pewarna dari cat minyak, cat air, pastel, dan pewarna tradisional.

Jika dibandingkan dengan lukisan Le Mayeur, koleksi lukisan Museum Puri Lukisan Ubud memiliki beberapa kemiripan. Di antaranya, gaya atau aliran dari beberapa sampel lukisan yang dipilih oleh peneliti di Museum Puri Lukisan Ubud memperlihatkan gaya representatif, hanya saja di Museum Puri Lukisan Ubud memiliki nama tersendiri untuk gaya atau aliran seni lukisnya. Tema yang diangkat juga sudah mulai berkembang dari awalnya berkutat pada pewayangan dan cerita-cerita mitologi menjadi ke arah kehidupan sosial masyarakat sekitar, pemandangan alam sekitar, dan lainnya lagi yang beberapa di antaranya sejenis dengan tema lukisan Le Mayeur. Teknik pewarnaan sudah memiliki kemiripan dengan lukisan Le Mayeur yaitu menggunakan pewarna modern dan memperhatikan pengetahuan bentuk, plastisitas, pengolahan ruang, dan teknik melukis secara lebih efisien. Walaupun sekilas banyak kemiripan tetapi tetap memiliki perbedaan yang merupakan ciri khas dari tiap-tiap pelukis seperti pemilihan warna yang lebih mencolok atau sebaliknya, goresan tangan yang lebih kasar atau lembut, sudut pandang yang berbeda dari tiap pelukis, dan lainnya lagi.

Kerusakan koleksi lukisan Museum Le Mayeur dialami oleh masing-masing substratnya, yaitu secara fisik terjadi kerusakan seperti kotor, rapuh, retak, gelombang, kendor, gores, dan sobek. Secara biotis terjadi kerusakan seperti jamur, serangga, busuk, dan lainnya. Secara kimiawi terjadi kerusakan seperti karat, kristal, oksidasi, warna pudar, noda, dan lainnya.

Faktor-faktor penyebab kerusakan dari koleksi lukisan di Museum Le Mayeur disebabkan oleh faktor fisis, faktor kemis, faktor biotis, dan faktor manusia. Faktor fisis meliputi suhu dan kelembaban udara, intensitas cahaya, dan radiasi sinar ultra-violet. Faktor kemis meliputi polusi udara yang mengandung debu, uap air garam (pantai sanur), dan zat-zat yang dikeluarkan oleh asap dermaga dan pedagang sekitar museum. Faktor biotis timbul akibat serangan hama makhluk hidup meliputi serangga, tikus, tumbuh-tumbuhan seperti jamur dan mikroorganisme lainnya. Faktor manusia merupakan perbuatan baik itu disengaja atau tidak sengaja yang dapat merusak koleksi lukisan di Museum Le Mayeur.

\subsection{Teknik Konservasi Koleksi Lukisan di Museum Le Mayeur}

Tindakan konservasi koleksi lukisan mencakup keseluruhan hal-hal dan upaya yang dilakukan untuk menyelamatkan sebuah koleksi lukisan terhadap ancaman kerusakan. Langkah-langkah konservasi lukisan dapat ditempuh melalui dua cara antara lain tindakan preventif yaitu pencegahan kerusakan dan tindakan kuratif yaitu penyelamatan dengan mengobati koleksi yang telah mengalami kerusakan. Museum Le Mayeur melakukan kedua cara tersebut dalam upaya konservasi koleksi lukisannya.

Konservasi preventif, tindakan konservasi yang bertujuan pencegahan kerusakan untuk menghindarkan benda cagar budaya dari kerusakan yang lebih parah. Museum Le Mayeur melakukan beberapa jenis tindakan konservasi preventif seperti kontrol lingkungan yang mencakup stabilitas suhu dan kelembaban udara di Museum Le Mayeur, pengaturan pencahayaan di Museum Le Mayeur, kontrol terhadap bangunan dan penghijauan di Museum Le Mayeur. Tindakan preventif terhadap objek lukisan mencakup sistem pembersihan koleksi lukisan Museum Le Mayeur, pnyimpanan koleksi lukisan 
menggunakan vitrin, teknik menggantung lukisan yang tepat, dan penggunaan insektisida. Meningkatkan disiplin petugas dan pengunjung juga merupakan tindakan preventif yang dapat mencegah terjadinya kerusakan-kerusakan di Museum Le Mayeur.

$\begin{array}{ccr}\text { Konservasi } & \text { kuratif, } & \text { tindakan } \\ \text { konservasi } & \text { rehabilitatif } & \text { dengan }\end{array}$ memperbaiki koleksi dari kerusakan, dimaksudkan untuk mengembalikan keadaan lukisan yang telah terserang penyakit dan rusak, khususnya kondisi fisik. Konservasi kuratif tidak seutuhnya mengembalikan kondisi fisik seperti semula, namun setidaknya menyerupai atau mendekati bentuk dan keadaan awal mula dari koleksi tersebut. Adapun konservasi kuratif yang sudah dilakukan di Museum Le Mayeur yaitu teknik pengobatan semi kemis dan tindakan restorasi. Teknik pengobatan semi kemis merupakan tindakan pembersihan koleksi lukisan dengan menggunakan alkohol untuk mengangkat debu dan mikroorganisme yang menempel pada lukisan. Tindakan restorasi merupakan konservasi yang bertujuan mengembalikan suatu objek lukisan pada bentuk semula tanpa mengurangi nilainilai yang terkandung didalamnya. Tindakan restorasi ini meliputi penambalan lubang lukisan, memperbaiki sobekan lukisan, pemberian strip pada lukisan, penambahan kanvas baru, dan teknik restorasi cat atau lapisan gambar.

\section{Simpulan}

Berdasarkan hasil penelitian yang telah dilakukan oleh peneliti tentang aspek-aspek perawatan koleksi lukisan khususnya tentang teknik konservasi koleksi lukisan di Museum Le Mayeur, maka dapat disimpulkan sebagai berikut.

a. bahwa metode konservasi lukisan merupakan pelaksanaan konservasi yang memerlukan keahlian khusus dan ketelitian. karakteristik dari lukisan Le
Mayeur adalah representatif dengan tema wanita dan kehidupan sekitar, teknik pewarnaan menggunakan teknik plakat dengan cat minyak, cat air, cat tradisional, dan pastel. Secara umum terdapat beberapa jenis kerusakan koleksi lukisan Museum Le Mayeur seperti kerusakan secara fisik atau mekanik, kerusakan secara biotis, dan kerusakan secara kimiawi. Berbagai jenis kerusakan ini disebabkan oleh faktor fisis, faktor kemis, faktor biotis, dan faktor manusia.

b. Tindakan konservasi lukisan dapat ditentukan setelah melakukan survei terkait karakteristik lukisan, jenis kerusakan lukisan, faktor penyebab kerusakan, analisis data, dan perencanaan yang kemudian dilanjutkan dengan pelaksanaan kerja konservasi lukisan. Di Museum Le Mayeur telah dilaksanakan konservasi baik itu preventif dengan teknik pencegahan terhadap kerusakan, dan kuratif dengan teknik mengobati atau merestorasi lukisan yang telah mengalami kerusakan.

\section{Daftar Pustaka}

Ardika, I Wayan. 2007. Pusaka Budaya dan Pariwisata. Denpasar : Pustaka Larasan.

CCI. 2002. Know Your PaintingsStructure, Materials, and Aspects of Deterioration. CCI Notes 10/17. Diambil dari https://www.canada.ca/ canadianconservation-institute-notes.html (1 Oktober 2018)

Damajanti, Irma. 2007. Konservasi Preventif Karya Seni Lukis bagi Mahasiswa Seni. Institut Teknologi Bandung Journal Visual Art Vol 1 D No.3, 391- 
400. Diambil dari http://journal.itb.ac.id/index.php (2 Oktober 2018)

Dermawan, Agus T. 2006. Tradisi dan Reputasi. Jakarta: Mahameru Off Set Printing. Yogyakarta. Yogyakarta : Balai Arkeologi.

Dinas Kebudayaan Provinsi Bali. 2016. Buku Panduan Museum Le Mayeur. Denpasar: UPT. Museum Bali.

Subagiyo, Puji .Yosep. 1997/ 1998. "Kontrol Kerusakan Biotis: Perlakuan Kultural/Fisik, Penyinaran/Radiasi, Pemanasan, Pendinginan, dan Fumigasi”, dalam Jurnal Museografia No 1 Tahun 1997/1998 Halaman 3-5. Jakarta : Departemen Pendidikan dan Kebudayaan.

Sutaarga, Amir. 1997/1998. Pedoman Penyelenggaraan dan Pengelolaan Museum. Jakarta : Departemen Pendidikan dan Kebudayaan 